\title{
Quality of Life Initiative Fall 2018
}

\author{
Bob Oxley, PhD $^{1} \otimes^{a}$, Kamrie Davenport ${ }^{2}$ b , Edward L. Hager ${ }^{2}$ c, Dustin Mattei ${ }^{2}$ d, Sandra M. Taylor ${ }^{2}$ e \\ ${ }^{1}$ Applied Sociology, Dixie State University, ${ }^{2}$ Institute for Social Research, Dixie State University \\ Keywords: single mother, poverty line, wic, snap, quality of life \\ https://doi.org/10.36898/001c.12279
}

\section{Curiosity: Interdisciplinary Journal of Research and Innovation}

This case study collected data over three months to determine the probability of a 25 -year old-single mother with two children, ages three and four, to have a quality of life. The basic life variables selected for this case were groceries, daycare, health insurance, transportation cost, and housing. The study found that the single mother could not afford to pay for basic life expenses and would go into debt by roughly $\$ 1,218$ a month, depending on her spending choices. She works a fulltime job that pays $\$ 9$ an hour, bringing in a net income of $\$ 18,720$ per year. The mother of two would have to earn or receive help equaling $\$ 34,946.46$ a year to pay for the categories selected and an extra $\$ 1,200$ in yearly savings for emergencies to achieve the quality of life standard.

\section{This article is reprinted by permission from the Institute for Social Research at Dixie State University}

\section{Introduction}

The first project of Dixie State University's (DSU) Institute for Social Research (ISR) is a continuation of effort from the foundation organized by the Spring 2018 SOC 3010 Stratification and Inequality course and marks the beginning of the Quality of Life Initiative. The purpose of this study is to

\footnotetext{
a Bob Oxley is a faculty member at Dixie State University's Applied Sociology Department. He is also the coordinator of Institute for Social Research at DSU.

b Kamrie Davenport is a graduate from Dixie State University (DSU) in St. George, Utah. She attended DSU for a bachelor's in human communication in 2017, she continued for a second bachelor's in applied sociology and a certificate in social research methods in 2019. She worked as a member of the Institute for Social Research (ISR) in 2018 and 2019. In 2019, the ISR examined the cost of attending DSU as an eighteen-year-old freshman. Kamrie presented the findings at DSU's Research Symposium in Spring 2019. Kamrie is currently working on her master's degree in sociology at Arizona State University.

c After twenty years of military service, Edward L. Hager retired in May of 2016. After military retirement, Edward returned to school at Dixie State University in St. George, Utah to obtain his bachelor's degree in Applied Sociology. While studying for this degree, he became certified in Social Research. Upon receiving his degree, Edward moved from St. George, Utah to Salt Lake City, Utah, and began working for the Department of Veterans Affairs at the Salt Lake City, Utah VA hospital. At the same time, Edward began working on his master's degree in Social Work at Northcentral University.

d The Institute for Social Research (ISR) was founded in 2018 and Dustin was on the first team that launched the quality of life initiative. In fall of 2019 he was promoted to research coordinator. October 2017, he started a content analysis on the United States use of drone strikes. This research was presented spring 2018, at the Utah Conference of Undergraduate Research and the Dixie Symposium. Fall 2018, he developed a survey to research how social capital is transferred into the virtual world. He also helped with the creation of the nonprofit management minor, partnered with the Nonprofit Leadership Alliance.

e Sandra M. Taylor felt honored to be part of the Institute for Social Research (ISR) team at Dixie State University (DSU). As a member of the ISR team, she spent countless hours with her peers researching their project and working closely to present our findings. After receiving her Bachelor of Science degree in Applied Sociology, she was offered a job as a Licensed Practical Nurse (LPN)/Case Manager at a local community healthcare clinic. This position allows her to work with individuals/patients needing assistance managing Chronic Disease, Medication-Assisted Treatment (MAT) for opioid and alcohol addictions to help solve complex social problems.
} 
determine the quality of life available for a single 25-year-old mother with two children, ages three and four. This is an ideal type, and all the qualities of the individual were determined by the students of the Stratification and Inequality class.

"Quality of life" has many definitions, but for this case study in St. George, Utah, we defined it as the ability to achieve the bare minimum needs for the mother and two children on a wage of $\$ 9$ per hour for 40 hours a week. This example gives a total of $\$ 18,720$ a year before the removal of taxes. It was determined that $\$ 100$ a week would be needed, in addition to all the other items included in this study, to provide a cushion for the family of three in the event of a crisis.

The basic needs for this case study include only a small group of what individuals usually budget for in a month. We focused on five different variables of needs: groceries, daycare, health insurance, transportation, and housing. The annual cost of these variables, including savings would total $\$ 36,146.64$ per year. With the current purchasing power of a $\$ 9$ hourly wage, even working full time, these basic needs could not be met.

\section{Literature Review}

\section{Cost of Living}

Using cost of living data from the St. George Chamber of Commerce a comparison was made with other cities from surrounding states with similar population and demographics. The data includes comparisons on housing, groceries, utilities and health care (St George Chamber of Commerce, 2018). In addition, an article published on April 26, 2018 by The Spectrum was used in comparison to physical data gathered by the ISR. This article reported that high home prices are moving people into an already-congested rental market. Rents were reported at an all-time high in the first quarter of the year. A twobedroom apartment was would rent for $\$ 939$ a month in the first quarter, according to NAI Excel, a commercial real-estate group with an office in St. George (DeMille, 2018).

\section{Health Insurance}

The research team used bealtbinsurance.net as a resource for obtaining a health insurance quote, only to find that there were no plans available for the single mother's income level. Affordable Care Act was an option in this case study, but it would not include preventative care for her and her children. Since Children's Health Insurance Program (CHIP) or Medicaid would not qualify under the definition set for a quality of life, the only other resource for this mother and two children would be Family Healthcare. Here, she would be able to receive preventative healthcare and pay according to her income level, allowing her access to medical treatment and interventions that would otherwise be too costly. 


\section{Transportation}

Automobile pricing from edmunds.com was used to estimate the cost of transportation with the selected vehicle, a 2016 Honda Civic. Due to a lack of demographic information on the female in this case study and identifying markers on the vehicle selected for her, obtaining an accurate quote for auto insurance was impossible. The closest estimates we were able to find were from online car insurance figure 6 .

\section{Daycare}

The cost of daycare was obtained by visiting $A$ Child's World Daycare, Little Harvard Academy, and Dixie Kids Inc. and gathering the registration packets. The centers had registration fees in addition to their weekly rates. If a child is picked up later than scheduled, an added fee of $\$ 1$ per minute will be charged. This data was used to create weekly daycare tables for each of the centers. Three-time categories were used: 30 hours per week, 40 hours per week, and 50 hours per week. The purpose for these four categories are to account for the single mother's personal errands and appointments.

\section{Groceries}

The data, in the form of prices, were gathered in local stores in St. George, Utah. The grocery list consisted of six categories: produce, meats, grains, canned goods, dairy, and frozen goods. The data collected each week were exported with totals and graphs into a Google document each team member had access to. Then these data were entered into Statistical Package for the Social Sciences (SPSS) to gather accurate statistical information on monthly price averages, along with comparing how individual stores measured against one another. Walmart was consistently lowest in price. The tables and charts in the grocery section show the framework of a grocery list that was incorporated into the 90-day snapshot.

\section{Groceries}

The purpose of this collection was to capture a snapshot of the semester, i.e. three months or roughly 90 days. The 25 -year-old single mother of two children, ages three and four, needed to have a list that she would purchase from each month. The ISR created a list of proposed items and kept track price changes over the specified time period.

Price collection occurred twice a month, generally on a weekend. A full list of grocery items is available as part of the groceries variable table 2 . The overall intention was to monitor the list and detect change. A Google Doc was kept by the research team for data collection. Weekly totals were exported, and graphs were prepared to monitor changes. These were then put together to show a three-month progression for every category and monthly average cost.

The groceries variable table shows a full list of the individual items and the categories they fit under. The collections of this section were divided into a three-month summary of the six categories and an average total from the seven stores visited. Overall, the prices of the selected list items increased from 


\begin{tabular}{cc}
\hline & Spring Grocery List \\
\hline Large bag of big carrots & Lunch meat \\
Cereal & Frozen chicken breasts \\
Milk & 10 Campbell's soup cans \\
Cheese & 10 cans veggies \\
Pasta & 5 Mac N'Cheese \\
Peanut butter & Whole wheat bread \\
4 Chef Boyardee cans & Jam \\
Hot dogs & Bananas \\
Butter & $2.5 \mathrm{lbs}$ Apples \\
Dozen eggs & $5 \mathrm{lbs}$ Rice \\
\hline
\end{tabular}

Tables 2. Groceries Variables

\begin{tabular}{|c|c|c|c|c|c|}
\hline Produce & Meat & Grains & Canned Goods & Dairy & Frozen Goods \\
\hline Bananas & $\begin{array}{l}\text { Lunch } \\
\text { Meat }\end{array}$ & White Bread & Fruits & $\begin{array}{l}\text { Cheese } \\
\text { Block }\end{array}$ & Frozen Chicken \\
\hline Apples & Hot Dogs & Wheat Bread & Peas & Mayonnaise & Waffles \\
\hline $\begin{array}{l}\text { Bag of } \\
\text { Carrots }\end{array}$ & Bacon & Pasta Shells & Corn & Butter & Pizza \\
\hline Celery & & Pasta Noodles & Beans & Milk & Concentrate Apple Juice \\
\hline Cucumbers & & Mac N'Cheese & Pasta Sauce & Eggs & $\begin{array}{l}\text { Concentrate Orange } \\
\text { Juice }\end{array}$ \\
\hline Lettuce & & Cereal & Tuna & \multirow[t]{9}{*}{ Margarine } & \multirow[t]{9}{*}{ Concentrate Grape Juice } \\
\hline Potatoes & & Grain Bars & $\begin{array}{l}\text { Chicken Noodle } \\
\text { Soup }\end{array}$ & & \\
\hline \multirow[t]{7}{*}{ Tomatoes } & & $\begin{array}{l}\text { Oatmeal } \\
\text { Packets }\end{array}$ & Pasta Dinners & & \\
\hline & & $\begin{array}{l}\text { Cheese } \\
\text { Crackers }\end{array}$ & Jelly & & \\
\hline & & \multirow[t]{5}{*}{ Rice } & Peanut Butter & & \\
\hline & & & Apple Sauce & & \\
\hline & & & Mustard & & \\
\hline & & & Ketchup & & \\
\hline & & & Syrup & & \\
\hline
\end{tabular}

September to the high in October with a slight decline in November as seen in the monthly change graph. Each category seemed to fluctuate, though there were some instances of steady decline.

The framework of a grocery list that was incorporated into the 90-day snapshot was taken from students of 2018 Spring Semester Inequality and Stratification class at Dixie State University. This list was merely a building block but gave the Institute for Social Research a point to start from. There is no price data to accompany the simulated grocery list, but it provides a list of possible items and allows for further explanation of the data collected.

According to the graph depicting monthly change, the overall average cost of groceries experienced price swings. These changes were calculated by averaging the total collection each month and dividing it by the number of stores visited, then comparing the prices to the first month of the full data collection. The 


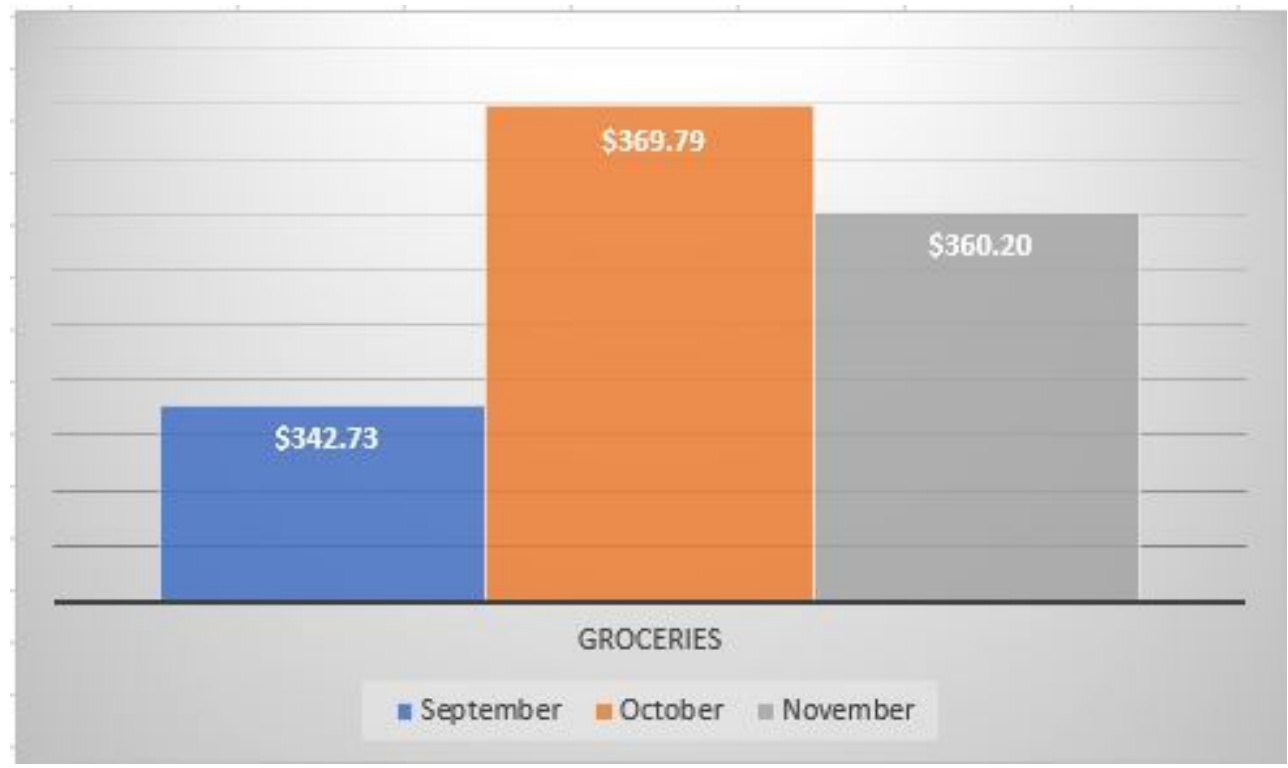

Figure 1. Monthly Average

simulated grocery list was applied with average cost of variable prices, detailed in the monthly price figure below, there was an increase of 6 percent in October and another 1 percent increase in November for a total of 7 percent over the three months. The increase in November occurred within the grocery list and not the variables priced.

The grocery list built from the monthly price figure borrows some of the matching items of the simulated grocery list table. The degree of increase appears small but may cause concern for the mother of two who makes $\$ 9$ per hour. This case study of a quality life, assuming the percent of increase remains stable for all the items on the list, would mean a change of $\$ 4.83$ spent weekly or $\$ 20.93$ per month. This would increase her yearly expenditure by $\$ 251.16$, assuming the rates stayed the same after November. This increase would eat from savings or would need to be offset by further help from state assistance or charity groups. Sales tax was not used in the final numbers because it did not change the percentage increase and would take the away from the raw numbers of grocery prices changing. Also, taxes are not paid by safety-net programs like WIC and food Stamp programs like SNAP.

\section{DAYCARE}

The single mother in this case would need to use daycare for her two children because she is working 40 hours a week. In order to find a daycare service that would meet the needs of the single mother, information was gathered from three of the major daycare services that are available in St. George, Utah. The Little Harvard Academy and Childcare, A Child's World, and Dixie Kids Inc. are the three daycare services that were examined. 
Figure 2. Monthly Price

\begin{tabular}{|c|c|c|c|c|c|}
\hline September & & October & & November & \\
\hline Bag of carrots & $\$ 1.44$ & Bag of carrots & $\$ 1.47$ & Bag of carrots & $\$ 1.75$ \\
\hline 4 pasta cans & $\$ 5.32$ & 4 pasta cans & $\$ 4.34$ & 4 pasta cans & $\$ 4.03$ \\
\hline Cereal & $\$ 1.89$ & Cereal & $\$ 2.86$ & Cereal & $\$ 2.96$ \\
\hline Hot dogs & $\$ 1.66$ & Hot dogs & $\$ 1.26$ & Hot dogs & $\$ 1.29$ \\
\hline Butter & $\$ 3.05$ & Butter & $\$ 3.23$ & Butter & $\$ 3.07$ \\
\hline 18 count eggs & $\$ 1.92$ & 18 count eggs & $\$ 2.05$ & 18 count eggs & $\$ 1.97$ \\
\hline Milk & $\$ 2.25$ & Milk & $\$ 2.22$ & Milk & $\$ 2.31$ \\
\hline Lunch meat & $\$ 3.26$ & Lunch meat & $\$ 2.52$ & Lunch meat & $\$ 2.50$ \\
\hline Cheese & $\$ 4.07$ & Cheese & $\$ 4.68$ & Cheese & $\$ 5.03$ \\
\hline Frozen chicken breast & $\$ 7.25$ & Frozen chicken breast & $\$ 6.11$ & Frozen chicken breast & $\$ 7.06$ \\
\hline 10 Chicken noodle soup & $\$ 8.23$ & 10 Chicken noodle soup & $\$ 8.49$ & 10 Chicken noodle soup & $\$ 8.82$ \\
\hline 4 Peas & $\$ 2.95$ & 4 Peas & $\$ 2.82$ & 4 Peas & $\$ 3.21$ \\
\hline 3 Corn & $\$ 1.94$ & 3 Corn & $\$ 1.95$ & 3 Corn & $\$ 1.87$ \\
\hline 3 Beans & $\$ 1.88$ & 3 Beans & $\$ 1.99$ & 3 Beans & $\$ 1.99$ \\
\hline Pasta & $\$ 0.83$ & Pasta & $\$ 1.11$ & Pasta & $\$ 1.15$ \\
\hline 5 Mac N'Cheese & $\$ 2.65$ & 5 Mac N'Cheese & $\$ 4.71$ & 5 Mac N'Cheese & $\$ 4.41$ \\
\hline Peanut Butter & $\$ 1.74$ & Peanut Butter & $\$ 1.78$ & Peanut Butter & $\$ 1.76$ \\
\hline Wheat Bread & $\$ 1.99$ & Wheat Bread & $\$ 2.17$ & Wheat Bread & $\$ 1.81$ \\
\hline Rice & $\$ 2.32$ & Rice & $\$ 4.22$ & Rice & $\$ 4.19$ \\
\hline Jelly & $\$ 1.87$ & Jelly & $\$ 2.29$ & Jelly & $\$ 2.18$ \\
\hline Bananas & $\$ 0.58$ & Bananas & $\$ 0.50$ & Bananas & $\$ 0.57$ \\
\hline 2.5lbs Apples & $\$ 2.89$ & 2.5lbs Apples & $\$ 3.16$ & 2.5lbs Apples & $\$ 2.87$ \\
\hline Total Weekly & $\$ 61.99$ & Total Weekly & $\$ 65.93$ & Total Weekly & $\$ 66.82$ \\
\hline Increase in \% & & & $6 \%$ & & $1 \%$ \\
\hline
\end{tabular}

\section{The Little Harvard Academy and Childcare}

Little Harvard Academy serves breakfast, a morning snack, lunch, an afternoon snack, dinner, and an evening snack. Their hours of operation are Monday through Friday, 6AM-9PM, and Saturday, 6AM-8PM. They also include a preschool, story time, song time, and an art experience. There is a $\$ 45$ registration fee.

The cost of daycare is divided into age groups. The 3-year-old and the 4-yearold fit into the same age group. The cost of daycare for each child at The Little Harvard Academy for 30 hours a week is $\$ 110$. For both children this comes to a monthly cost of $\$ 946$. The cost of daycare for 40 hours a week for each child is $\$ 130$. For both children this comes to a monthly cost of $\$ 1,118$. The cost of daycare for 50 hours a week for each child is $\$ 150$ a week. For both children this would come to a monthly cost of $\$ 1,290$. There is the assumption that both children are toilet trained. If the children were not toilet trained, there would be an additional fee of $\$ 25$ per month per child. These rates do not include the registration fee.

\section{A Child's World}

A Child's World Daycare includes breakfast, lunch, and an afternoon snack. Their hours of operation are Monday through Friday from 6:30AM to 6:30PM. They also offer a preschool. There is a $\$ 40$ registration fee. 
The cost of daycare for a 3-year-old at A Child's World Daycare would be $\$ 110$ for 4 days a week. For 5 days a week, this cost rises to $\$ 128$. The schedule is for up to 9 hours of daycare a day. After 9 hours, the cost goes up $\$ 5$ per every 15 minutes. If the child needs to stay after hours, there is a fee of $\$ 1$ per minute that is charged before the child is picked up that evening.

The cost of daycare for a 4-year-old at A Child's World Daycare would be $\$ 103$ for 4 days a week, rising to $\$ 118$ for 5 days. This schedule is set up for up to 9 hours of daycare a day. After 9 hours, the rate goes up $\$ 5$ per every 15 minutes. If the child needs to stay after hours, there is a fee of $\$ 1$ per minute that is charged when the child is picked up that evening.

The cost of daycare for two children for 4 days a week is $\$ 213$. Per month, this would be $\$ 852$. For 5 days a week, the cost is $\$ 246$. Per month, this would be $\$ 984$.

\section{Dixie Kids Inc.}

The hours of operation at Dixie Kids Inc. is 6:30AM to 6:30PM, Monday through Friday. This daycare includes preschool and a kindergarten for children who attend. There is a $\$ 25$ registration fee.

The cost of daycare for a 3-year-old for less than part time daycare (24 hours a week or less) is $\$ 88$. For part time daycare (25-30 hours a week), the cost is $\$ 108$. For full time (over 30 hours a week), the cost is $\$ 120$. If the 3-year-old is not toilet trained, there is an additional charge of $\$ 10$ per week. If the child needs to be picked up after the hours of operation, there is a charge of $\$ 1$ per minute that the parent is late.

The cost of daycare for a 4-year-old for less than part time (24 hours a week or less) is $\$ 85$. The cost of daycare for part time (25-30 hours a week) is $\$ 100$. For full time (over 30 hours a week) the cost is $\$ 110$. The $\$ 1$ per minute late charge for after hours of operation applies to the 4-year-old child, too.

The cost for two children for less than part time (24 hours a week or less) would be $\$ 173$. Per month, this would amount to $\$ 692$. For part time (25-30 hours a week), the cost would be $\$ 208$, totaling $\$ 832$ per month. For full time (over 30 hours a week), the cost would be $\$ 230$. Per month, this would be $\$ 920$.

\section{Health Insurance}

For a single mother and her two children (a 3-year-old and a 4-year-old), private insurance may be cost prohibited. As of 2018, Utah's minimum wage is stipulated to be $\$ 7.25$ per hour. As a research team, we decided that this single mother would be earning $\$ 9.00$ an hour. Working 40 hours a week, this would add up to $\$ 1,280$ a month and approximately $\$ 16,000$ to $\$ 20,000$ as an annual salary. Healthcare.gov would not verify private insurance coverage for this single mother due to the study being a hypothetical case. The ISR lacked necessary demographic information. We were referred to healthinsurance.net, where the best policy available for this single mother and her two children was an Accident \& Sickness Hospital Indemnity Insurance that did not offer any preventative care for $\$ 61.31$ a month. According to the Federal Guidelines on Appendix Figure 4, a family of 3 making $\$ 20,780$ a year or less is below the 


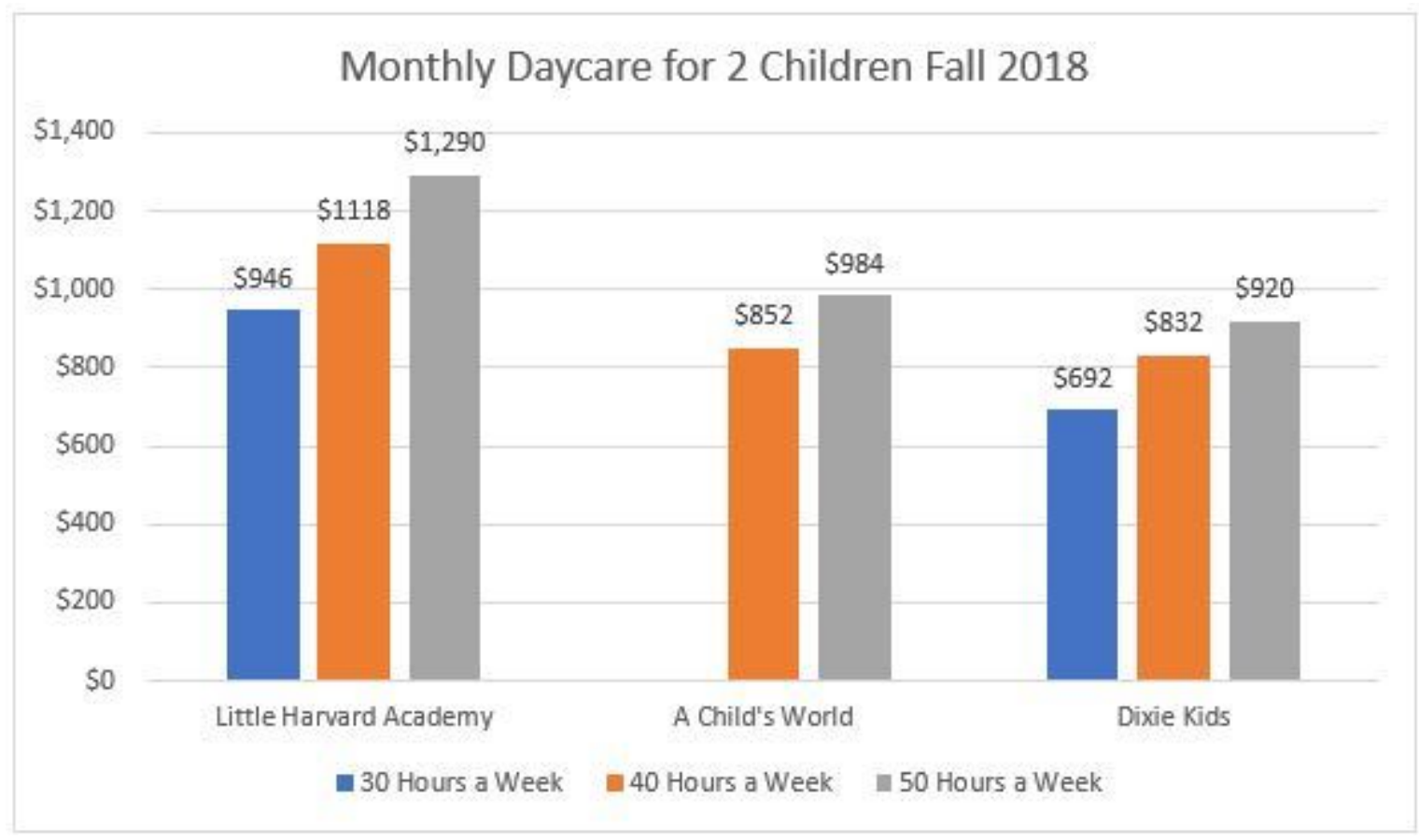

Figure 3. Monthly Daycare

\begin{tabular}{|c|c|}
\hline PERSONS IN FAMILY/HOUSEHOLD & POVERTY GUIDELINE \\
\hline \multicolumn{2}{|c|}{ For families/households with more than 8 persons, add $\$ 4,320$ for each additional person } \\
\hline 1 & $\$ 12,140$ \\
\hline 2 & $\$ 16,460$ \\
\hline 3 & $\$ 20,780$ \\
\hline 4 & $\$ 25,100$ \\
\hline
\end{tabular}

Figure 4. Poverty Guideline

poverty level. Based on this income, we were directed to the Affordable Care Act for possible medical plans. However, we required additional demographic information (e.g, Social security number, date of birth) in order to gain acceptance.

The research team explored within the City of St. George for a cost-effective health plan that would work with the mother's income and allow her access to medical treatment for all of her and her family's health care needs. Family Healthcare (FHC) is a medical clinic that would work with this single mother and her children. FHC clinics work with patients on a sliding fee schedule based on income as seen in figure 5 family healthcare sliding fee schedule. 


\begin{tabular}{|c|c|c|c|c|c|}
\hline sed & $\begin{array}{l}\text { Ss Published Janua } \\
\text { CategoryA }\end{array}$ & & & & \\
\hline $\begin{array}{c}\text { MEDICAL } \\
\text { Nominal Fees }\end{array}$ & $\$ 25.00$ & $\$ 40.00$ & $\$ 50.00$ & $\$ 55.00$ & $\begin{array}{l}100 \% \text { (Deposit: } \\
\text { New } \$ 113 \text { Est \$93; } \\
\text { Patient will be billed } \\
\text { the remaining) }\end{array}$ \\
\hline $\begin{array}{c}\text { DENTAL } \\
\text { Nonimal Foes }\end{array}$ & $\$ 39.00$ & $\$ 61.00$ & $\$ 71.00$ & $\$ 81.00$ & $100 \%$ \\
\hline $\begin{array}{c}\text { MENTAL } \\
\text { Nominal Fees }\end{array}$ & $\$ 10.00$ & $\$ 12.00$ & $\$ 14.00$ & $\$ 16.00$ & $\begin{array}{c}100 \% \text { (Deposit: New } \\
\$ 150 \text { Est \$72; pationt } \\
\text { will be billed the } \\
\text { remaining) }\end{array}$ \\
\hline \multirow[t]{2}{*}{ LAB Fees } & $\$ 25.00$ & $\$ 30.00$ & $\$ 35.00$ & $\$ 40.00$ & $100 \%$ \\
\hline & $\begin{array}{l}\text { Up to } 100 \% \text { of Federal } \\
\text { Poverty Level }\end{array}$ & $\begin{array}{l}101 \% \text { to } 133 \% \text { of Federal } \\
\text { Poverty Level }\end{array}$ & $\begin{array}{l}134 \% \text { to } 150 \% \text { of Federal } \\
\text { Poverty Level }\end{array}$ & $\begin{array}{l}151 \% \text { to } 200 \% \text { of Federal } \\
\text { Poverty Level }\end{array}$ & $\begin{array}{l}\text { Over } 200 \% \text { of Federal } \\
\text { Poverty Level }\end{array}$ \\
\hline Family Size & $\begin{array}{c}\text { Monthly Income_Yearly } \\
\text { Income }\end{array}$ & $\frac{\text { Monthly Income Yearly }}{\text { Income }}$ & $\begin{array}{c}\text { Monthly Income-Yearly } \\
\text { Income }\end{array}$ & $\frac{\text { Monthly Income-Yearly }}{\text { Income }}$ & $\begin{array}{c}\text { Monthly Income Yearly } \\
\text { Income }\end{array}$ \\
\hline 1 & $\$ 1,012$ & $\$ 1,346$ & $\$ 1,518$ & $\$ 2,023$ & Over $\$, 2,023$ \\
\hline 1 & $\$ 12,140$ & $\$ 16,146$ & $\$ 18,210$ & $\$ 24,280$ & Over $\$ 24,280$ \\
\hline 2 & $\$ 1,372$ & $\$ 1,824$ & $\$ 2,058$ & $\$ 2,743$ & Over $\$ 2,743$ \\
\hline 2 & $\$ 16,460$ & $\$ 21,892$ & $\$ 24,690$ & $\$ 32,920$ & Over $\$ 32,920$ \\
\hline 3 & $\$ 1,732$ & $\$ 2,303$ & $\$ 2,598$ & $\$ 3,463$ & Over $\$ 3,463$ \\
\hline 3 & $\$ 20,780$ & $\$ 27,637$ & $\$ 31,170$ & $\$ 41,560$ & Over $\$ 41,560$ \\
\hline 4 & $\$ 2,092$ & $\$ 2,782$ & $\$ 3,138$ & $\$ 4,183$ & Over $\$ 4,183$ \\
\hline 4 & $\$ 25,100$ & $\$ 33,383$ & $\$ 37,650$ & $\$ 50,200$ & Over $\$ 50,200$ \\
\hline 5 & $\$ 2,452$ & $\$ 3,261$ & $\$ 3,678$ & $\$ 4,903$ & Over $\$ 4,903$ \\
\hline 5 & $\$ 29,420$ & $\$ 39,129$ & $\$ 44,130$ & $\$ 58,840$ & Over $\$ 58,840$ \\
\hline 6 & $\$ 2,812$ & $\$ 3,740$ & $\$ 4,218$ & $\$ 5,623$ & Over $\$ 5,623$ \\
\hline 6 & $\$ 33,740$ & $\$ 44,874$ & $\$ 50,610$ & $\$ 67,480$ & Over $\$ 67,480$ \\
\hline 7 & $\$ 3,172$ & $\$ 4,218$ & $\$ 4,758$ & $\$ 6,343$ & Over $\$ 6,343$ \\
\hline 7 & $\$ 38,060$ & $\$ 50,620$ & $\$ 57,090$ & $\$ 76,120$ & Over $\$ 76,120$ \\
\hline 8 & $\$ 3,532$ & $\$ 4,697$ & $\$ 5,298$ & $\$ 7,063$ & Over $\$ 7,063$ \\
\hline B & $\$ 42,380$ & $\$ 56,365$ & $\$ 63,570$ & $\$ 84,760$ & Over $\$ 84,760$ \\
\hline 9 & $\$ 3,892$ & $\$ 5,176$ & $\$ 5,838$ & $\$ 7,783$ & Over $\$ 7,783$ \\
\hline 9 & $\$ 46,700$ & $\$ 62,111$ & $\$ 70,050$ & $\$ 93,400$ & Over $\$ 93,400$ \\
\hline 10 & $\$ 4,252$ & $\$ 5,655$ & $\$ 6,378$ & $\$ 8,503$ & Over $\$ 8,503$ \\
\hline 10 & $\$ 51,020$ & 607,85 & 576,530 & $\$ 102,040$ & Over $\$ 102,040$ \\
\hline
\end{tabular}

Figure 5. Family HealthCare Sliding fee schedule

Allowing individuals access to preventative visits, dental exams, cancer screenings, mental health services, referral services, prescriptions, immunizations, labs, and other medical procedures at a contracted price. This single mother would pay $\$ 25.00$ for a clinic office visit, $\$ 39.00$ for a dental exam or cleaning, and $\$ 10$ dollars for mental health services.

Intermountain Healthcare is aware of the level of poverty in St. George and provides Family Healthcare vouchers for diagnostics, ultrasounds, MRI's, CT scans, X-rays, mammograms. For patients to qualify for this voucher, they must be an established patient with Family Healthcare, have lived in Utah for at least 90 days, and have current proof of income on file. The patient can then purchase the voucher for $\$ 50$ dollars. The patient then takes the voucher and medical provider's order to an IHC facility. The voucher covers the cost of all laboratory work and part of any diagnostic imaging needed. The radiologist, however, charges a separate fee, and the patient will receive a separate bill. The patient can then call to make payment arrangements to the number on their billing statement if needed. A discount will be given for patients who have a voucher which will be applied to their bill. Without this voucher, system individuals and families like this case study would have to pay without a discount. 


\begin{tabular}{|c|c|c|c|c|c|c|}
\hline Website & Company & Coverage & $\begin{array}{l}\text { Towing/Rent a } \\
\text { car }\end{array}$ & Deductible & $\begin{array}{l}\text { Monthly } \\
\text { Payment }\end{array}$ & $\begin{array}{l}\text { Total per } \\
\text { year based } \\
\text { on monthly } \\
\text { premium }\end{array}$ \\
\hline nerdwallet.com & Sun Coast & $50,000 / 100,000 / 50,000$ & $\begin{array}{l}\text { Yes } \\
\text { Rental-\$30 per } \\
\text { day } \\
\text { Towing } \$ 75 \text { per } \\
\text { disablement }\end{array}$ & $\$ 500.00$ & $\begin{array}{l}99.00 \\
+ \\
\text { possible } \\
\text { down } \\
\text { payment }\end{array}$ & $\$ 1,188$ \\
\hline Progressive.com & Progressive & $50,000 / 100,000 / 15,000$ & Yes & $\$ 500.00$ & $\begin{array}{l}\$ 113.96 \\
+ \\
\text { possible } \\
\text { down } \\
\text { payment }\end{array}$ & $\$ 1,367.52$ \\
\hline StateFarm.com & State Farm & $50,000 / 100,000 / 50,000$ & Yes & $\$ 500.00$ & $\begin{array}{l}\text { \$154.81 } \\
+ \\
\text { possible } \\
\text { down } \\
\text { payment }\end{array}$ & $\$ 1,857.72$ \\
\hline thegeneral.com & The General & $50,000 / 100,000 / 50,000$ & $\begin{array}{l}\text { Yes } \\
\text { Rental-\$30 per } \\
\text { day } \\
\text { Towing } 775 \text { per } \\
\text { disablement }\end{array}$ & $\$ 500.00$ & $\begin{array}{l}\$ 219.16 \\
+ \\
235.17 \\
\text { down } \\
\text { payment } \\
+\$ 25.00 \\
\text { policy fee }\end{array}$ & $\$ 2,629.92$ \\
\hline
\end{tabular}

Figure 6. Car Insurance

\section{Auto insurance for a 2016 Honda Civic}

Collecting information in person from local insurance agencies was not possible due to lack of demographic information on a 25-year-old female (e.g., Social security number, date of birth) and lacking identifying markers (e.g., vehicle VIN number) on the Honda Civic. As a research team, we wanted a plan that would give the single mother a level of security along with affordability. We desired full coverage that would not exceed 50/100/50 and a deductible of $\$ 500$. This would be realistic for a single 25 -year-old's income. Also, the team wanted her to have access to a rental car and towing, which on some policies included an additional fee. Through sifted online quotes, the most cost-effective plans that offer possible rent-a-car, roadside assistance, and towing are displayed in Figure 6. From the rates collected, Sun Coast has the best rate for this case study. It is $\$ 99.00$ a month, $\$ 1,188.00$ a year. This plan gives her roadside coverage and rental car benefits that would be necessary in the event of an accident or if her car broke down. Please refer to the car insurance figure 6 for a breakdown of all the plans.

\section{Transportation Cost}

A 2016 Honda Civic averages 15,000 miles a year (See Appendix Vehicle fuel and mileage data). To fill a 12.4-gallon tank it costs an average of $\$ 3.14$ per gallon. The research team looked at fuel prices during the months of August through October and found that they fluctuated. From July thru August, the cost of a gallon of gas averaged at $\$ 3.20$, with a slight increase during the month of September, which averaged $\$ 3.14$ per gallon. It continued to decline in the month of October, where the average reached $\$ 3.06$ for a gallon of gas. The research team estimated that this single mother would fill her 12.4-gallon tank 


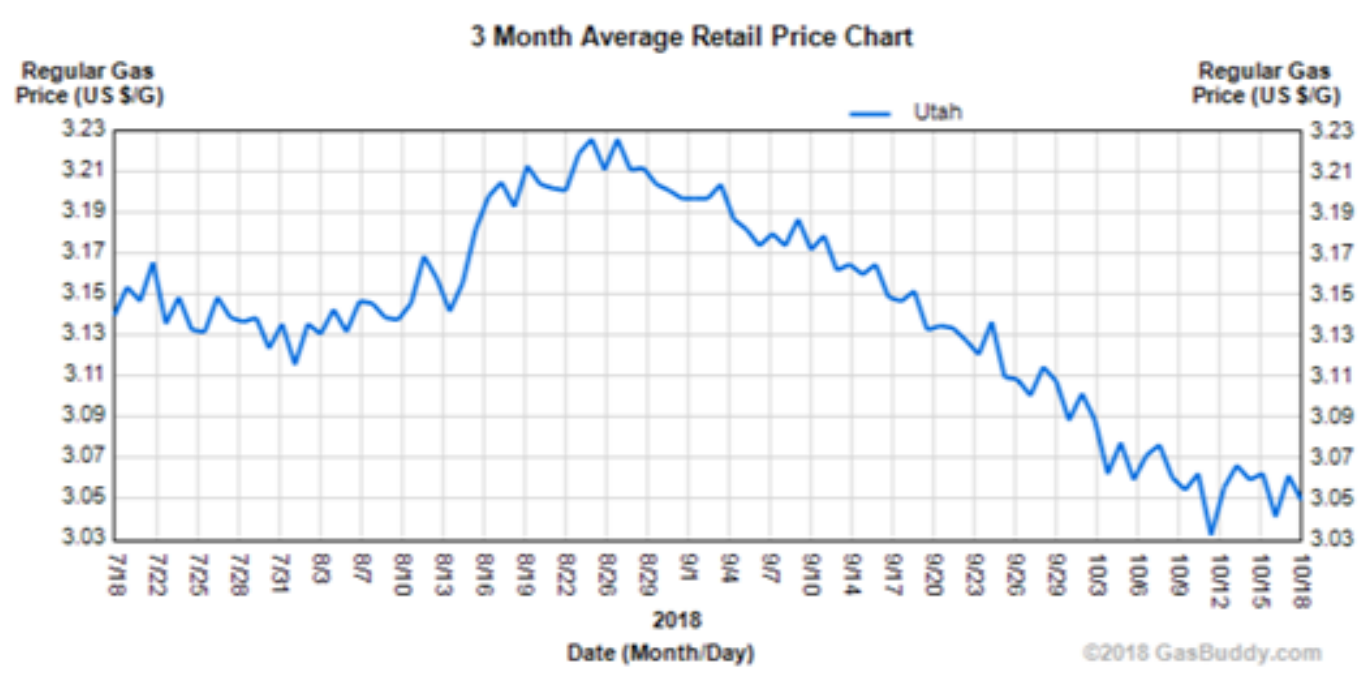

Figure 7. July-October Gas Price Average

bi-weekly for about $\$ 37.94$ to $\$ 39.68$. The average 90-day snapshot (See Figure 7) shows a pattern in decreasing gas prices that persists. Other potential costs for maintenance and repairs were taken into consideration as expenditures for monthly savings.

\section{Apartment Housing}

The research team collected rental pricing data on September 15 th and 16 th. Prices were collected from Desert Rose Apartments, Grayhawk Apartments, Legacy Ridge Apartments, and The Falls at Mesa Point Apartment Community all in St. George. We made inquiries on rental prices of two and three-bedroom apartments. The apartments selected to meet the quality of life (e.g., close to schools, parks, grocery stores, and medical services) had two bedrooms and were in a desirable area with access to community resources.

Rent ranges from $\$ 1,230$ (1088 Sq. Ft.) with one bath to \$1,265 (1092 Sq. Ft.) with one bath per month. If the unit had two bathrooms, rent increased to $\$ 1,600$ per month for up to $1671 \mathrm{Sq}$. Ft. as seen in figure 8 . We were able to obtain several lease agreements and an estimate of additional fees that were not listed in their brochures. Most apartments require a \$35 application fee per adult that will be residing at the property. Deposits are typically $\$ 300$ to $\$ 400$ but can be a full month's rent depending on credit scores. A $\$ 200$ lease initiation fee (which is non-refundable) is also needed prior to occupation of the apartment. Utilities are not included, as most or all apartment managers required renters to set up those services independently. Some charge $\$ 80$ to $\$ 85$ per month for internet that must be carried with the provider of the manager's choosing, and it may or may not include cable.

One parking space is normally included, but additional parking can be $\$ 45$ up to $\$ 100$ dollars a month if the tenant wants covered parking. If this single mother has good credit and minimal fees apply to her lease, she will need $\$ 1,754$ to $\$ 1,848$ as an initial payment just to rent an apartment that would meet the standard quality of life. In rent alone, this single mother would be paying $\$ 13,500$ to $\$ 14,760$ a year. 


\begin{tabular}{|c|c|c|c|c|c|c|c|}
\hline Apartment Name & $\begin{array}{l}2 \\
\text { Bedroom }\end{array}$ & $\begin{array}{l}3 \\
\text { Bedroom }\end{array}$ & $\begin{array}{l}\text { Application } \\
\text { Fee }\end{array}$ & Deposit & \begin{tabular}{l|} 
Utilities \\
Included
\end{tabular} & Cable/Internet & Parking \\
\hline Oasis & $\$ 1,213$ & $\$ 1,463$ & $\begin{array}{l}\$ 35.00 \text { Per } \\
\text { adult }\end{array}$ & $\$ 600.00$ & None & & $\begin{array}{l}\text { ? parking } \\
\text { Move in Total } \\
\text { including fees } 2 \\
\text { Bedroom base line } \\
\text { apt. } \$ 1, \$ 4 \$ \text { (based } \\
\text { on } \$ 1,213 \text { a month) }\end{array}$ \\
\hline Legacy Rich & $\begin{array}{l}\$ 1,125.00- \\
\$ 1,505.00\end{array}$ & & $\begin{array}{l}\text { \$35. per } \\
\text { adult }\end{array}$ & $\begin{array}{l}\$ 200 \text { based } \\
\text { on } \\
\text { credittlease } \\
\text { fee of } \\
\$ 299.0+\operatorname{tax} \\
\$ 10.00\end{array}$ & & $\$ 85.00$ & $\begin{array}{l}1 \text { parking spot } \\
\text { included additional } \\
\text { parking } 45.00 \\
\text { Move in Total } \\
\text { including fees } 2 \\
\text { Bedroom } \\
\text { \$1,754 (based on } \\
\$ 1,125 \text { a month) }\end{array}$ \\
\hline Grayhawk & $\begin{array}{l}\$ 1,230- \\
\$ 1,600\end{array}$ & $\begin{array}{l}\$ 1,475.00- \\
\$ 1,625\end{array}$ & & $\begin{array}{l}\text { 2B-\$300 } \\
\text { 3BD-\$400 } \\
+\$ 200 \\
\text { lease fee }\end{array}$ & & $\$ 85.00$ & $\begin{array}{l}\text { ? parking } \\
\text { Move in Total } \\
\text { including fees } \\
2 \text { Bedroom } \\
\text { \$1,\$15 (based on } \\
\$ 1,230 \text { a month) }\end{array}$ \\
\hline
\end{tabular}

Figure 8. Apartment Rent comparison

\section{Conclusion}

With living expenses totaling $\$ 2,912.22$ per month and the mother of two working for $\$ 9$ dollars an hour would total $\$ 1,560$ a month net pay. This leaves a resource gap of $\$ 1,352.22$ without removing income taxes and other withholdings. This case study resolves that without intervention by other social structures via safety net programs or charity from private organizations, a quality life for these individuals is not possible. The single mother does not have the resources available on her own to access the quality life defined by the ISR research team. Further research is needed to address how taxes would affect vulnerable populations like this single mother with two children. 


\section{References}

Cost of living comparison: Compare Spokane, Washington to Rancho San Diego, California. (n.d.). BestPlaces. Retrieved 2018, from https://www.bestplaces.net

DeMille, D. (2018). St. George workers struggle to afford southern Utah homes. The Spectrum. https://www.thespectrum.com/story/news/2018/04/20/st-george-utah-home-prices-outpaceincomes $/ 536711002$

GasBuddy. (n.d.). https://www.gasbuddy.com

Get 2018 health coverage. Health insurance marketplace. (n.d.). Retrieved 2018, from https://www.healthcare.gov

St George Chamber of Commerce. (2018). St. George Area Chamber of Commerce. https://www.stgeorgechamber.com 